\title{
Impact of Covid-19 on Society, Economics and Education of Nigeria
}

\section{Gbenemene Kpae}

University of Port Harcourt, Nigeria

\begin{abstract}
The impact of coronavirus on the Nigerian society cannot be over-emphasized. The Nigerian economy and education are the two most important sectors that have been greatly impacted by the pandemic. Since most Nigerians rely on the informal sector for their sustenance, the government shorting down the economy meant extreme poverty for most families. More importantly, school closure due to the pandemic also means more Nigerian children, especially the poor and those that reside in the rural communities would be deprived of education, since they would not have access to the modern form of IT based e-learning. This digital divide means children from lower socio- income background would be left behind in education and may lack the necessary skills to stay ahead in the future, due to the absence of a national government policy on ways of tackling the disruption to education due to Covid-19 pandemic.
\end{abstract}

Keywords-Covid-19, pandemic, society, economics, education, Nigeria.

\section{INTRODUCTION}

COVID 19 pandemic is one of the deadliest and scariest various that has ever besieged humanity since the Spanish flu of 1918. In the history of mankind, no virus has ever threatened human existence such as COVID 19. Although before the Spanish flu of 1918, there was the mention of plagues in the Bible Old Testament book of Exodus when King Pharaoh refused to set the Israelites free and allowthem to leave Egypt.But the Spanish pandemic was the virus with deadly consequences that still remains in the history of humanity.According to the U.S.Centres for Disease Control, the Spanish influenza of 1918-1919 claimed the lives of about 200,000 Americans in the month of October, while an estimated 25 million people (25\% of the total population of 103 people) became ill and 675,000 died of the virus in less than 2 years of its outbreak (Byerly, 2014).But the impact of the Egyptian plaque, and Spanish flu combined including SARS virus, HIV Aids and Ebola cannot be compared to COVID 19 pandemic.The greatest fear associated with Covid-19 virus is that it can be transmitted through contact, droplets, and fomites, and by people who are asymptomatic (WHO, 2020). As a result, people are forced to remain isolated for fear of spreading the pandemic.Globally,over 33 million people have beeninfected with corona virus; while over 1 million people have died from the virus.In the U.S. alone it is projected that by 2021 , over 300,000 people would have died from the virus. In Europe, there is upsurge in the spread of the disease prompting several governments to impose additional curfew and lockdown to contain its spread. In Nigeria, there are over 58,000 confirmed cases with over 1000 deaths.

The impact of Covid-19 on global economy has been debilitating as many international flights have had to lay off their workers, while some are turning to digital or online ticket reservation in order to reduce the cost of operation. In addition, over 1 billion children in primary, secondary and universities worldwide have been asked to stay at home as measures to prevent the spread of Covid-19 (UNESCO, 2020). As a result of the isolation, the transition from traditional classroom learning to online education has become the only remedy, in order to reduce the obstruction to the educational system. However, in Nigeria the impact of the pandemic is still heavily felt by the people despite the ease on lockdown due to economic hardship and because of the disparity in access to online tools needed for education among children in various class structures in our society. The economic crunch due to Covid-19 has rendered most families poor and unable to maintain a source of livelihood. This paper, therefore, examines the impact of COVID 19 on Nigerian society, economy and education. 


\section{LITERATURES REVIEW}

\section{Impact of COVID 19 on Nigerian Society}

It is no doubt that the coronavirus pandemic has impacted nearly every aspect of Nigerian society, particularly the economy and education. Also impacted by Covid-19 crisis include the religious and social life of the people, health, entertainment etc. Nigerians culturally are communal in nature but the pandemic has altered the way that most people relate to one another including visiting of relatives, family members, friends, and burial of loved ones. The ability of most Nigerians to relate with one another was also hindered by government directives prohibiting gathering in public places including bars, restaurants, gymnasium, parks etc. The government directives included outright ban to restriction of gathering to just fifty persons in public places. Apart from that, in the rural areas, local farmers and fisher men and women who rely on daily fishing and farming were affected by the lockdown due to the corona virus crisis. As a result, many families lost their major sources of livelihood.

\section{Impact of COVID on Nigerian Economy}

Coronavirus pandemic has very devastating impact on the Nigerian economy, due to the peculiar nature of the informal sector to the Nigerian economy. Many Nigerians rely on daily activities for sustenance, such as retail sales and buying of goods and services.More significantly, since the Nigerian economy depends heavily on crude oil and gas sales for her foreign reserve earning, Covid-19 almost grounded the nation's economy due to fall in global demand for crude oil. The macroeconomic impact of the pandemic on Nigeria's economy includes loss in federal government earnings due to fall in crude oil price, slow GDP growth rate, high inflation and high unemployment level (Farayibi\&Asonga, 2020). Prior to the pandemic, the Nigerian economy was already struggling due to fall in global oil price, but the corona virus further puts the economy in fragile situation due to closure of many companies. Apart from the oil sector that has been impacted by COVID-19 pandemic, other sectors including maritime, tourism, banking, hospitality and entertainment, health, agriculture, aviation etc. In describing the negative impact of the pandemic on the Nigerian economy the Minister of Finance, Budget and National Planning, Zainab Ahmed, noted that the Nigerian economy prior to the virus was already fragile and vulnerable. She added that the pandemic has resulted in unprecedented disruption in global supply chain, drop in crude oil prices, turmoil in global stock and financial markets, and the lockdown of movements of persons in many countries. The minister also noted that the pandemic has had tremendous impact on households' livelihoods and business activities resulting from a drop in global demand, declined consumer confidence and slowdown in production. This economic situation led the government to reverse the 2020 budget by slashing its revenue projection to about $40 \%$, and seeking emergency support from the International Monetary Fund, the World Bank, and the African development Bank in order to execute its 2020 budget. Similarly, the Lagos Chamber of Commerce and Industry (LCCI) believe the pandemic has led to unprecedented fall in commodity prices, capital flight, turmoil in capital market, supply chain disruption in all sectors, and destabilization of commercial and economic activities (.APC News, 2020).

To be more specific, the oil and gas sector was negatively impacted by the pandemic due to the decline in global oil prices (the Brent Crude), Nigeria's benchmark grade, which dropped by $60 \%$ since the beginning of 2020 . The crash in global oil prices necessitated the adjustment of the reference price of crude oil from $\$ 57$ per barrel to $\$ 30$, and further down to $\$ 20$ in order to implement the 2020 budget.Additionally, the 2021 budget has a deficit of N4.65 trillion due to declining revenue from oil as a result of the pandemic.This means that the Nigerian government might not be able to finance most of her infrastructural development projects by 2021, if the revenue from oil continues to decline(Wole, 2020).

The aviation and banking sectors were never spared by the pandemic as flight operations were short down and only limited banking operations were allowed in major cities around the country, while some bank branches were closed down outrightly. The aviation and bankingsectors also laidoff several of their employees due to the pandemic. Other sectors that were worst heat by the pandemic are the hospitality and entertainment industry and health. The lockdown led to the closure of many hotels and film and entertainment companies due to the pandemic, while, the crisis exposed the rot and dearth in the basic infrastructure in the Nigerian health sector. For instance, a survey conducted by the LCCI on the impact of Covid 19 crisis on business community showed that the pandemic had a significant impact on business in Lagos business community as people had about N500, 000losses in revenue daily. Furthermore, Nigeria's inflation rate also rose due to Covid-19 from $12.13 \%$ in January, to $12.82 \%$ in July, 2020 during the peak of the lockdown (Oyekami, 2020). The price of food items 
increased due to short supply of staple foods such as rice, garri, beans, millet and maize in the market.

\section{Impact of COVID 19 on the Education Sector}

Education is another sector that has been impacted by Covid 19 pandemic. The pandemic led to the closure of schools across the country. Prior to the pandemic, the Nigeria government has been struggling to ensure that it provide quality education to her growing youthful population, and reduce the school dropout rate. But this situation is made worst with the Covid-19 pandemic as only limited number of children from fairly confortable homes can afford to provide online education for their children, thereby living the greater number of children poorly educated during the lockdown. According to the United Nations,COVID-19 pandemic has created the largest disruption of education systems in history, affecting nearly 1.6 billion learners in more than 190 countries and in all continents. Furthermore, the UN stated the closures of schools and other learning spaces have impacted 94 per cent of the world's student population, up to 99 per cent in low and lower-middle income countries (UN, 2020).

The crisis, according to the UN has exacerbated pre-existing education disparities by reducing the opportunities for many of the most vulnerable children, youth, and adults particularly those living in poor or rural areas, girls, refugees, persons with disabilities and forcibly displaced persons to continue their learning. Learning losses also threaten to extend beyond this generation and erase decades of progress, not least in support of girls and young women's educational access and retention. Some 23.8 million additional children and youth (from pre-primary to tertiary) may drop out or not have access to school next year due to the pandemic's economic impact alone (UN, 2020).

In a low income country such as Nigeria, the government owned public schools could not provide online education for their students, except some few private schools. Prior to the pandemic, Nigeria had been struggling to keep its children in school due to high rate of school dropout. In fact, Nigeria contributes approximately $20 \%$ of the total global out-of school children. This figure is likely to increase due to the pandemic and the income gap between the rich and poor in the country. According to a UNICEF report, 10.5 million Nigerian children aged 5-14 years are out school. Only $61 \%$ of 6 to 11 year olds attend primary school regularly. Some states in the north east and north west of the country have more than half of the young girls not enrolled in schools due to cultural biases against women education (Amorighoye, 2020).

According to the International Labour Organization (ILO) more than 70 percent of youth who study or combine study with work have been adversely affected by closure of schools, universities and training centres. In another report on the impact of Covid-19 on jobs, education, rights and mental well-being, $65 \%$ of the youths reported learning less since the beginning of the pandemic as a result of the transition from classroom to online and distance learning during the lockdown. The situation is worst for youths from low income countries that have less access to internet, a lack of equipment and sometime lack of space at home. The ILO report also highlighted the big digital divides between regions; that is, while $65 \%$ youths from high income countries were taughtclasses via video lectures, only $18 \%$ of low income countries were able to conduct online classes for their youths. According to Hussain (2020) the impact of Covid-19 on Nigerian education is tremendous because the government did not have the technology to carter for the 46 million students affected by the pandemic. She noted that unlike other developed countries, the Nigerian government did not have any clear-cut policy measures on how to mitigate learning disruptions for children or how to mitigate the digital divide. Thus children from higher socio-economic background are less likely to experience disruption to their learning because they attend private schools and their schools are well-equipped with ICT infrastructure, and the parents can afford remote learning resources at home. Conversely, the majorities of the students are from vulnerable and disadvantage backgrounds, which do not have access to computers and other devices outside school. In many cases, these children are either from impoverished homes in urban centres or live in communities with poor or non-existent internet connectivity and unreliable power supply. Inevitably, this digital divide will exacerbate the learning disparities among these children, and the socioeconomic disparity between the rich and poor in the country.

\section{Efforts by Government to Mitigate the Effect of Covid-19 Crisis on Society, Economics and Education}

In an effort to reduce the impact of the pandemic on the society, the government is gradually easing down on social gathering especially marriage ceremonies, church weddings and burials. The government has also easing down on the economy so that many lower income families that depend on daily sales of goods and services including fishing and farming for sustenance to be able to go about their 
businesses. Notwithstanding the easing of the economy by the government, inflation rates continue to climb higher making the cost of food items to be outside the reach of many ordinary Nigerians. Furthermore, in order to mitigate the digital divide between children from low socio-economic background and well off families, the governments of most countries such as the U.S., Australia, China, etc are providing laptops computers and internet services to indigent children. However, in Nigeria, all the government could provide is learning through local media channels such as radio progrrammes so as to reach out to children from poor homes and in rural communities, but these radiolearning methods have had very limited impact on the children due to the epileptic power supply and inability of the government to sustain the programme.

\section{Empirical Findings}

Ogunode (2020) conducted a research using a survey design method to determine the effect of Covid-19 on education among teachers and senior secondary school pupils in Abaji area in FCT, Abuja, Nigeria. He found that overwhelming majority of the respondents $(100 \%)$ believed that school closure as a result of Covid-19 has affected academic programme of senior secondary schools. He also found that school closure has affected the academic calendar of senior secondary in the FCT. He recommended that the government should come up with strategies to cover the gap in education occasioned by school closure due to Covid-19 pandemic.
In contrast, Duraku and Hoxha (2020) examined the impact of COVID-19 on education and on the well-being of teachers, parents, and students: Challenges related to remote (online) learning and opportunities for advancing the quality of education in Kosovo. Their aim was to explore the concerns of parents, students and teachers due to the social isolation and the concern of parents, teachers and students relating to online education. The study adopted a qualitative research design. Semi-structured interviews were used to elicit information from respondents in the 14 municipalities and 7 regions of Kosovo. The study found that there was a successful implementation of online education in Kosovo. The factors that contributed to the successful implementation of the online school programme in Kosovo include the relatively high number of citizens who are ICT users. In fact, over $70 \%$ of Kosovo citizens are internet users, rural dwellers and from low-income families. Further, $64 \%$ of the participants reported having internet at home, while $94 \%$ of them reported using the internet the most in their homes (Duraku\&Hoxha, 2020). This finding by Duraka and Hoxha tends to contradict the findings in Ogunode (2020) and the situation in Nigeria where most children in rural communities do not have access to the internet and the unreliable power situation makes online learning difficult for most students from poor homes and rural dwellers.

Farayibi\&Asonga (2020) examined the economic impact of Covid-19 in Nigeria, and found that Covid-19 pandemic has insignificantly caused a decline in the macroeconomics of Nigeria. Specifically, the crisis led to fall in the nation's GDP growth rate due to fall in oil price, which made the federal government to cut down on its budget expenditure, and then borrow money to execute the 2020 budget. Apart from fall in GDP, the country also experienced high inflation, and high unemployment rate. Relying on data obtained from the National Bureau of Statistics daily online report, Farayibi and Asonga noted that an analysis of the trend of macroeconomics variables due to Covid-19 was a fall in oil price due to low demand from the international market as a result of reduction in people's movement and grounding of airline operation around the globe. He concluded that Covid-19 had a negative impact on major macroeconomics variables in Nigeria such as GDP growth rate, inflation, unemployment rate, oil price, and exchange rate. 


\section{CONCLUSION}

Corona virus pandemic has caused great scare on the global economy, since it involves the restriction of movement in order to reduce spread of the virus. In Nigerian, the impact of the pandemic has been tremendous especially on the education sector due to school closure. Many public schools had difficulties transiting from classroom to online education because of the cost of providing such IT education. Unfortunately, many children from low income families, especially those living in rural communities are left out and continue to fall behind in the educational disparity between the rich and poor.

Covid-19 affected greatly low income families who rely on income earned from daily sales of food items for their sustenance. The informal sector is the biggest employer of most people, and with the lockdown and restriction of movement as a result of the Covid-19 crisis, many families struggled to survive during the peak of the lockdown. Although, the government is beginning to ease the lockdown and restriction of movements, but the economic impact of the pandemic is still felt by many people. Unemployment rate continue to rise $(27.1 \%$ up from $23.1 \%$ of the third quarter of 2018) with 25 million graduates unemployed.Food prices continue to skyrocket and not within the reach of many struggling families.Many of those who lost their jobs during the pandemic are yet find gainful employment. This macroeconomic downturn has been made worst by the fallen crude oil price which makes it difficult for government to implement its fiscal budget of 2020.Although, the government has introduced some palliative schemes especially to private business owners by making grants available to them, but this measure seem not to cushion the hardship faced by many people due to Covid-19 pandemic.Driven by economic difficulties, many Nigerians particularly the youths have vent their anger against the government through violent street protest and vandalizationof government properties including buildings of notable personalities in society. In reaction, the government has imposed curfew in several states across the country in order to ease the tension.

\section{RECOMMENDATIONS}

As, many state governments are beginning to open schools in Nigeria, priority should be given to ICT education, which should run side by side with classroom learning; unfortunately, many government owned schools are ill- equipped with information technology, thereby making many children from poor homes who attend public schools not to be at par with their mates in private schools.

We also recommend that the government should provide palliatives to indigent families who would be struggling to survive due to the pandemic.

The macroeconomic policies of government should focus more on providing employment for her teaming youthful population, as well as providing an enabling environment conducive for businesses to thrive.

Lastly, the government should provide grants to private businesses particularly small and medium scale business owners in order to revitalize the economy.

\section{REFERENCES}

[1] Amorighoye, T.A. (2020) Covid-19 Has exposed the education divide in Nigeria. This is how we can close it. World Economic Forum Covid Action Plan.www.weforum/agenda/2020/06/education-nigeria-covid19. Accessed 26/9/2020

[2] APA News (2020) Nigerian economy and the traumatic impact of Covid-19 pandemic. Apanews.net/news/Nigerianeconomy. Accessed 25/9/2020

[3] Byerly, C. (2014). The Influenza Pandemic of 19181919, History Now 40, The GilderLehrman Institute of American history, https.www.gilderlhman.org/historynon/essays/influenza-pandemic-1918.

[4] Duraku, Z.Y. \&Hoxha, L. (2020)The impact of COVID-19 on education and on the well-being of teachers, parents, and students: Challenges related to remote (online) learning and opportunities for advancing the quality of education. www.researchgate.net/publication. Accessed 27/9/2020.

[5] International LabourOrganisation (2020) Youth and Covid19: Impacts on Jobs, education, Rights and Mental Health. www.ilo.org/global/about-the-ilo/news

[6] Hussain, T.A. (2020). Education and Covid-19 in Nigeria: Tackling the Digital Divide.www.worldliteracyfoundation.org/education-andcovid-19-in-nigeria. Accessed 26/9/2020

[7] Farayibi, A. \&Asonga, S. (2020).The Economic Consequences of Covid-19 Pandemic in Nigeria. Electronic Journal.www.reearchgate.net. Accessed 28/9/2020

[8] Ogunode, N.J. (2020) Effect of Covid-19 Schools Close Down on Academic. Programme of Senior Secondary Schools in Abaji Area Council of Federal Capital Territory, Abuja, Nigeria. Electronic Research Journal of Social Sciences and Humanities, 2(11): 84-94 
[9] Oyekami, S. (2020). Nigeria's Inflation Jumps to $12.82 \%$, highest in 27 months. Nirametrics.www.nirametrics/2020.Accessed 30/9/2020

[10] UNESCO (2020).Covid-19 Impact on Education Data. Covid-19 Education Disruption and Response. The United Nations Education, Scientific and Cultural Organization, UNESCO United Nations (2020). Policy Brief: Education during COVID-19 and Beyond.

[11] World Health Organization (2020) Q\&A: Influenza and COVID-19-Similarities and Differences.

www.who.net/emergencies/diseaase/novel-coranavirus-19. Accessed 29/9/2020.

[12] Wole, O. (2020) Highlights: Federal Government of Nigeria Budget Proposal. www..kpmg/ng/en/home/insight Accessed 10/11/2020. 